Volume I Tahun 2021

November 2021
E-ISSN: 2808-5361 http://e-journal.fkmumj.ac.id/
Proceeding The First

Muhammadiyah Internasional-

Public Health and Medicine

Conference

\title{
Evaluation of Iso 9001:2015 Risk Control in Case of Used Antigen Swab
}

\author{
Ferry Meiliawan \\ Faculty of Public Health, Muhammadiyah University of Jakarta \\ K.H. Ahmad Dahlan St, Cireundeu, Ciputat, South Jakarta, 15419 \\ E-mail: ferrymeiliawan@gmail.com
}

\begin{abstract}
The number of domestic passengers departing from the Medan Polonia airport was on average as many as hundreds of thousands of passengers per month. Where every passenger is required to carry out a covid antigen examination, one of which is an antigen swab examination. At the end of April 2021, the Police uncovered a case of using a used antigen test kit at Kualanamu Airport. Therefore, the author tries to evaluate and review the antigen swab process in Kualanamu Medan to take technical steps for riskrelated assessments at the antigen swab sampling facility. This research design uses a literature study by studying theories and secondary data. Based on data obtained from the Statistics Agency as many as hundreds of thousands of people using domestic flights from Polonia airport. To reduce risk organizations make the existing process risks, namely, the sampling process, specimen examination, data analysis and supervision from the head office, where the probability risk greatly affects the organization. The five steps of improving diagnostic pharmaceutics are considered good in solving the problems at hand, but perhaps the additional implementation of improvements must be carried out more consistently and using risk base thinking and PDCA cycle.
\end{abstract}

Keywords: Risk base thinking, PDCA, ISO 9001:2015, Antigen swab 
E-ISSN: 2808-5361 http://e-journal.fkmumj.ac.id/
Proceeding The First Muhammadiyah InternasionalPublic Health and Medicine

Conference

\section{INTRODUCTION}

Health is one of the things that greatly affect humans to carry out their daily activities. Without human health, it will not be productive to live a decent life both economically and in education. Health is a human right and one of the elements of welfare that must be realized following the ideals of the nation contained in the Pancasila and the 1945 Constitution of the Republic of Indonesia. Article 34 paragraph (3) of the 1945 Constitution, as a result of the amendments, states that the state is responsible for the provision of proper health care facilities and public service facilities. ${ }^{12}$

To reduce the number of Covid transmissions in air transportation modes, Coordinating Minister for Maritime Affairs and Investment Luhut Panjaitan requires passengers of all transportation modes to show negative antigen swab results. This obligation is effective from 18 December 2020. ${ }^{5}$

The government has renewed the travel requirements and validity period of the PCRantigen swab for domestic travelers. This provision will be effective as of April 1, 2021. This latest travel condition is stated in the Circular Letter (SE) of Task Force Number 12 of 2021. This provision replaces the previous SE Number 7 of 2021.

Air transportation travelers are required to show a certificate of negative RT-PCR test results whose samples were taken within 3 X 24 hours before departure or negative rapid antigen test results whose samples were taken a maximum of $2 \times 24$ hours or negative results of the Genoese $\mathrm{C} 19$ test at the airport before departure. ${ }^{6}$

Clinical Laboratory is a health laboratory that carries out clinical specimen examination services to obtain information about individual health, especially to support efforts to diagnose disease, cure disease, and restore health. ${ }^{10}$

At the end of April 2021, the police uncovered a case of using a used antigen test kit at Kualanamu Airport, Deli Serdang, North Sumatra. At least five suspects were arrested by the authorities.

The suspects were arrested after opening the practice of recycling long sticks or cotton buds which are used as a tool to carry out antigen swab tests. The trick, they wash again, clean, and repackage the sticks so they look new. ${ }^{7}$

The President Director of Kimia Farma Diagnostics, Adil Fadhilah Bulqini, emphasized that the actions taken by these individuals were contrary to the Standard Operating Procedure (SOP). ${ }^{9}$ 
E-ISSN: 2808-5361 http://e-journal.fkmumj.ac.id/
Proceeding The First Muhammadiyah InternasionalPublic Health and Medicine

Conference

Islam teaches safety and security at work, based on HR. Ibn Majah. Book of Al Ahkam 2340 states that the Prophet Muhammad recommended

"It must not cause harm and must not harm other people"

Risk and danger cannot be separated from every work and human life. The definition of risk is complex and very broad, but broadly speaking, the risk is an opportunity for loss or something that is not expected and has the impact of problems that can affect human life. ${ }^{4}$

ISO 9001:2015 does not direct us to apply risk-based thinking only at the beginning of the design of the quality management system, but we need to apply this thinking periodically during management reviews and determine corrective actions to be taken. This means that top leaders also need to play an active role in encouraging the application of this risk-based thinking for the sake of the continued effectiveness of the quality management system run by the organization.

The management system approach applied in the above problem is based on the Plan-DoCheck-Act (PDCA) concept.

The PDCA concept is an iterative process used by organizations to achieve continuous improvement. This system can be applied to the management system and each of its elements, as follows:

a) Plan/Plan: determine and assess risks, opportunities, and other risks and other opportunities, establish goals and processes needed to deliver results in accordance with organizational policies;

b) Do/Do: implement the process as planned;

c) Check: monitor and measure activities and processes related to the policy, and report the results. ${ }^{1}$

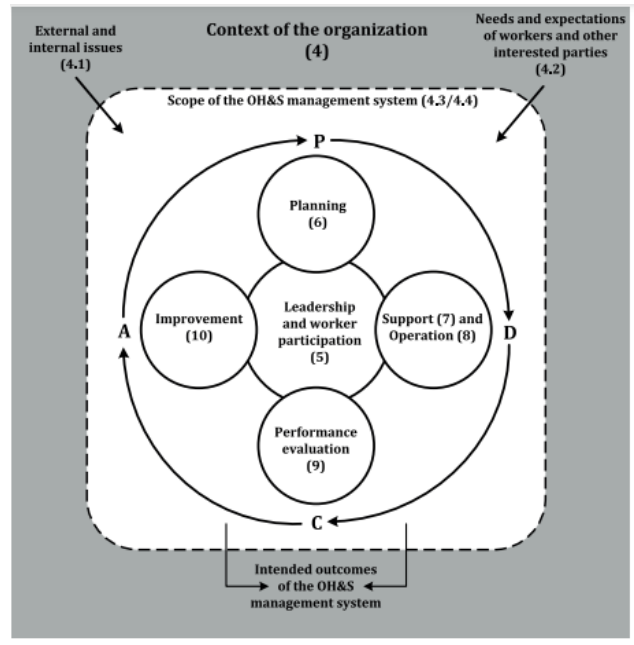


E-ISSN: 2808-5361 http://e-journal.fkmumj.ac.id/
Proceeding The First Muhammadiyah InternasionalPublic Health and Medicine

Conference

Figure 1. Scope of the OH\&S Management System

\section{METHODS}

Literature study and ISO 9001:2015 management system approach based on risk-based thinking with the concept of Plan-Do-Check-Act (PDCA).

\section{RESULTS AND DISCUSSIONS}

From the flight data, it can be seen that there are almost 100 thousand passengers per month who fly from January to April 2021 at the Polonia airport, the domestic terminal, so it is very worrying for this swab check by using an antigen swab using used ones by washing them.

\begin{tabular}{l|l|l|l|l|l|}
\hline & \multicolumn{5}{l}{ Jumlah Penumpang Pesawat di Bandara Utama (Orang) } \\
\cline { 2 - 7 } & Keberangkatan pada Penerbangan Domestik \\
\hline & 2021 & & \\
\hline Bandara Utama & Januari & Februari & Maret & April & Mei \\
\hline Polonia & 157614 & 100191 & 122498 &. &. \\
\hline Soekarno Hatta & 507262 & 482132 & 672107 &. &. \\
\hline Juanda & 189560 & 152366 & 198457 &. &. \\
\hline Ngurah Rai & 118962 & 71049 & 116888 &. &. \\
\hline Hasanudin & 163992 & 128429 & 166182 &. &. \\
\hline
\end{tabular}

Figure 2. Number of Aircraft Passengers at Main Airport Departures on Domestic Flights

So to reduce the risk that the same will happen in the future, the author will try to make a risk register related to the process that is roughly the root cause or the root of the problem that will or is likely to occur.

ISO 9001:2015 does not direct us to apply risk-based thinking only at the beginning of the design of the quality management system, but we need to apply this thinking periodically during management reviews and determine corrective actions to be taken. This means that top leaders also need to play an active role in encouraging the application of this risk-based thinking for the sake of the continued effectiveness of the quality management system run by the organization.

Sseveral things that are in the ISO 9001:2015 standard related to risks, opportunities, and risk-based thinking, as a reference for making risk-based thinking in each activity process such as:

1. "The organization shall establish the processes required for the quality management system and its implementation throughout the organization and shall: address risks and opportunities as determined." (Item $\mathrm{f}$ in clause 4.4.1)

2. "Top management must demonstrate leadership and commitment to the quality management system by promoting the use of a process approach and risk-based thinking." (Item $\mathrm{d}$ in clause 5.1.1) 
E-ISSN: 2808-5361 http://e-journal.fkmumj.ac.id/
Proceeding The First Muhammadiyah InternasionalPublic Health and Medicine

Conference

3. "Top management must demonstrate leadership and commitment to customer focus by ensuring that: risks and opportunities that may affect conformance to products and services and the ability to improve customer satisfaction are identified and addressed." (Item b clause 5.1.2)

4. "When planning a quality management system, organizations must consider issues and requirements and determine risks and opportunities." (Clause 6.1.1)

5. "Organizations must plan: actions to address risks and opportunities." (Item a clause 6.1.2)

6. "The organization shall analyze and evaluate the appropriate data and information arising from monitoring, measurement. The results of the analysis should be used to evaluate: the effectiveness of the actions taken to address risks and opportunities." (Item e clause 9.1.3)

7. "Management reviews should be planned and implemented taking into account: the effectiveness of actions taken to address risks and opportunities." (Item e clause 9.3.2)

8. "When nonconformities occur, including any complaints that arise, the organization shall: update the risks and opportunities identified during planning, if necessary." (Item e clause 10.2 .1

So from some of the things above, the authors make a risk register and a matrix related to the core process of taking the antigen swab below:

Table 1. List of risks

\begin{tabular}{|c|c|c|c|c|c|c|c|}
\hline $\begin{array}{c}\text { Aktifitas } \\
\text { (Item Resiko) } \\
\text { (1) }\end{array}$ & $\begin{array}{l}\text { Issue } \\
\text { (2) }\end{array}$ & $\begin{array}{c}\text { Impact } \\
\text { (Dampak) } \\
\text { (3) }\end{array}$ & \begin{tabular}{|c} 
Severit \\
$y$ \\
(Kepar \\
ahan) \\
(4)
\end{tabular} & $\begin{array}{l}\text { Potensial } \\
\text { Cause } \\
\text { (Penyebab } \\
\text { Potensial) } \\
\text { (5) }\end{array}$ & $\begin{array}{c}\text { Probability } \\
\text { (Kemungk } \\
\text { inan) } \\
\text { (6) }\end{array}$ & $\begin{array}{c}\text { Risk } \\
\text { Priority } \\
\text { Number } \\
\text { (RPN) } \\
\text { (7) }\end{array}$ & $\begin{array}{c}\text { Action Plan } \\
\text { (Rencana Tindak Lanjut) } \\
\text { (8) }\end{array}$ \\
\hline \multicolumn{8}{|l|}{$\begin{array}{c}\text { proses pengambilan } \\
\text { sampel }\end{array}$} \\
\hline \multirow[t]{2}{*}{ 1. peryiapan ala! swab } & akemasan rusak & $\begin{array}{c}\text { Teriadimya kesalatan } \\
\text { pengukuran }\end{array}$ & 3 & $\begin{array}{l}\text { (MAN, } \\
\text { METHOD, } \\
\text { MATERLAL) }\end{array}$ & 1 & 3 & 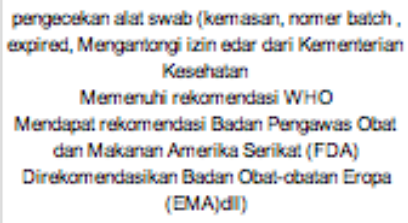 \\
\hline & $\begin{array}{l}\text { b.sik barubah } \\
\text { warna, berbas, } \\
\text { bergerigi }\end{array}$ & $\begin{array}{l}\text { Terjadimya kesdiatan } \\
\text { pengukuran, cross } \\
\text { cortamination }\end{array}$ & 3 & $\begin{array}{l}\text { (MAN, } \\
\text { METHOD, } \\
\text { MATERIAL) }\end{array}$ & 1 & 3 & 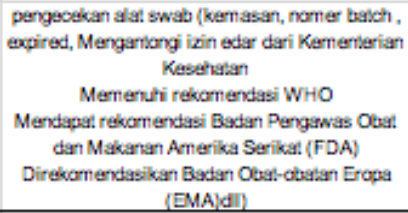 \\
\hline
\end{tabular}


Volume I Tahun 2021

November 2021
E-ISSN: 2808-5361

http://e-journal.fkmumj.ac.id/
Proceeding The First

Muhammadiyah Internasional-

Public Health and Medicine

Conference

\begin{tabular}{|c|c|c|c|c|c|c|c|}
\hline $\begin{array}{c}\text { Aktifitas } \\
\text { (Item Resiko) } \\
\text { (1) }\end{array}$ & $\begin{array}{l}\text { Issue } \\
\text { (2) }\end{array}$ & $\begin{array}{l}\text { Impact } \\
\text { (Dampak) } \\
\text { (3) }\end{array}$ & $\begin{array}{c}\text { Severit } \\
y \\
\text { (Kepar } \\
\text { ahan) } \\
\text { (4) }\end{array}$ & $\begin{array}{c}\text { Potensial } \\
\text { Cause } \\
\text { (Penyebab } \\
\text { Potensial) } \\
\text { (5) } \\
\end{array}$ & $\begin{array}{c}\text { Probability } \\
\text { (Kemungk } \\
\text { inan) } \\
\text { (6) }\end{array}$ & $\begin{array}{c}\text { Risk } \\
\text { Priority } \\
\text { Number } \\
\text { (RPN) } \\
\text { (7) }\end{array}$ & $\begin{array}{c}\text { Action Plan } \\
\text { (Rencana Tindak Lanjut) } \\
\text { (8) }\end{array}$ \\
\hline \multicolumn{8}{|l|}{$\begin{array}{l}\text { 2. selesai pemeriksaan } \\
\text { spesimen }\end{array}$} \\
\hline $\begin{array}{l}\text { a. pertilungan alat swab } \\
\text { bekas pakai }\end{array}$ & $\begin{array}{l}\text { salah hitung } \\
\text { jumlath pernakaian }\end{array}$ & $\begin{array}{l}\text { Terjadinya selisith } \\
\text { barang masuk dan } \\
\text { keluar }\end{array}$ & 3 & $\begin{array}{l}\text { (MAN, } \\
\text { METHOD, } \\
\text { MATERLAL) }\end{array}$ & 1 & 3 & 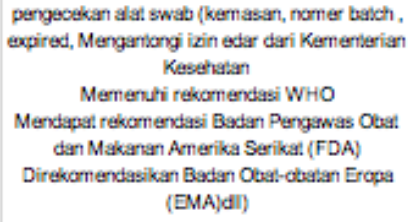 \\
\hline $\begin{array}{l}\text { b. pengumpulan ala! } \\
\text { swab sudaht pakai }\end{array}$ & dpaksi kembali & $\begin{array}{l}\text { Sdak dikumpulkan pada } \\
\text { vempatmya , dlaporkan } \\
\text { jumlah pemakaian dan } \\
\text { cross cortaminafion }\end{array}$ & 3 & $\begin{array}{l}\text { (MAN, } \\
\text { METHOD, } \\
\text { MATERLL) }\end{array}$ & 1 & 3 & $\begin{array}{l}\text { pelaparan jumlah alat lest yang dipakai dan } \\
\text { laporan manilest yang dsupervsisi }\end{array}$ \\
\hline $\begin{array}{l}\text { c. pemberian marilest } \\
\text { ke pithak yang dituriuk }\end{array}$ & $\begin{array}{l}\text { pintak yang } \\
\text { diuriuk sdak ada } \\
\text { ada iin }\end{array}$ & $\begin{array}{l}\text { pencemaran lingkungan } \\
\text {, cross contaminaton }\end{array}$ & 3 & $\begin{array}{l}\text { (MAN, } \\
\text { METHOD, } \\
\text { MATERIAL) }\end{array}$ & 1 & 3 & $\begin{array}{l}\text { pelaporan jumlah alat vest yang dipakai dan } \\
\text { laporan manilest yang disupervsisi }\end{array}$ \\
\hline
\end{tabular}

\begin{tabular}{|c|c|c|c|c|c|c|c|}
\hline $\begin{array}{c}\text { Aktifitas } \\
\text { (Item Resiko) } \\
\text { (1) }\end{array}$ & $\begin{array}{l}\text { Issue } \\
\text { (2) }\end{array}$ & $\begin{array}{c}\text { Impact } \\
\text { (Dampak) } \\
\text { (3) }\end{array}$ & $\begin{array}{c}\text { Severit } \\
y \\
\text { (Kepar } \\
\text { ahan) } \\
\text { (4) }\end{array}$ & $\begin{array}{l}\text { Potensial } \\
\text { Cause } \\
\text { (Penyebab } \\
\text { Potensial) } \\
\text { (5) }\end{array}$ & $\begin{array}{c}\text { Probability } \\
\text { (Kemungk } \\
\text { inan) } \\
\text { (6) }\end{array}$ & $\begin{array}{c}\text { Risk } \\
\text { Priority } \\
\text { Number } \\
\text { (RPN) } \\
\text { (7) }\end{array}$ & $\begin{array}{c}\text { Action Plan } \\
\text { (Rencana Tindak Lanjut) } \\
\text { (8) }\end{array}$ \\
\hline \multicolumn{8}{|c|}{$\begin{array}{l}\text { 3. Supervivisi Kantor } \\
\text { pusat }\end{array}$} \\
\hline a. internal Audi! & $\begin{array}{c}\text { Man } \\
\text { (kampelansi,) } \\
\text { Methode } \\
\text { (prosedur). } \\
\text { Machine ( ala! } \\
\text { Test), Material ( } \\
\text { als! swab) }\end{array}$ & $\begin{array}{l}\text { gap , keperesyaan } \\
\text { publik berkurang }\end{array}$ & 3 & $\begin{array}{l}\text { (MAN, } \\
\text { METHOD, } \\
\text { MATERLAL) }\end{array}$ & 1 & 3 & jadwal imtarnd audi, audior no cornlict of imterset. \\
\hline
\end{tabular}

\begin{tabular}{|c|c|c|c|c|c|c|c|}
\hline $\begin{array}{c}\text { Aktifitas } \\
\text { (Item Resiko) } \\
\text { (1) }\end{array}$ & $\begin{array}{l}\text { Issue } \\
\text { (2) }\end{array}$ & $\begin{array}{c}\text { Impact } \\
\text { (Dampak) } \\
\text { (3) }\end{array}$ & $\begin{array}{c}\text { Severity } \\
\text { (Keparahan) } \\
\text { (4) }\end{array}$ & \begin{tabular}{|c|} 
Potensial \\
Cause \\
(Penyebab \\
Potensial) \\
(5) \\
\end{tabular} & $\begin{array}{c}\text { Probability } \\
\text { (Kemungkin } \\
\text { an) } \\
\text { (6) }\end{array}$ & $\begin{array}{l}\text { Risk Priority } \\
\text { Number } \\
\text { (RPN) } \\
\text { (7) }\end{array}$ & \begin{tabular}{|c|} 
Action Plan \\
(Rencana \\
Tindak \\
Lanjut) \\
(8)
\end{tabular} \\
\hline \multicolumn{8}{|l|}{$\begin{array}{l}\text { 4. Proses } \\
\text { input data } \\
\text { hasil }\end{array}$} \\
\hline $\begin{array}{c}\text { a. pembuatan } \\
\text { hasil }\end{array}$ & $\begin{array}{l}\text { salah input } \\
\text { data }\end{array}$ & $\begin{array}{l}\text { kepercayaan } \\
\text { publik } \\
\text { berkurang }\end{array}$ & 3 & $\begin{array}{c}\text { (MAN, } \\
\text { METHOD,MA } \\
\text { CHIN,MATE } \\
\text { RIAL) }\end{array}$ & 1 & 3 & $\begin{array}{c}\text { Kompetensi, } \\
\text { prosedur( no } \\
\text { urut, nama } \\
\text { orng,dll), } \\
\text { cek bahan } \\
\text { yang dipakai }\end{array}$ \\
\hline $\begin{array}{l}\text { a. pemberian } \\
\text { hasil ke } \\
\text { pelanggan }\end{array}$ & $\begin{array}{c}\text { salah hasil } \\
\text { dan salah } \\
\text { orang }\end{array}$ & $\begin{array}{l}\text { kepercayaan } \\
\text { publik } \\
\text { berkurang }\end{array}$ & 3 & $\begin{array}{c}\text { (MAN, } \\
\text { METHOD,MA } \\
\text { CHIN,MATE } \\
\text { RIAL) }\end{array}$ & 1 & 3 & $\begin{array}{c}\text { Kompetensi, } \\
\text { prosedur( no } \\
\text { urut, nama } \\
\text { orng ,dll), } \\
\text { cek bahan } \\
\text { yang dipakai }\end{array}$ \\
\hline
\end{tabular}


Volume I Tahun 2021

November 2021
E-ISSN: 2808-5361

http://e-journal.fkmumj.ac.id/
Proceeding The First Muhammadiyah Internasional-

Public Health and Medicine

Conference

Table 2. Risk Matrix

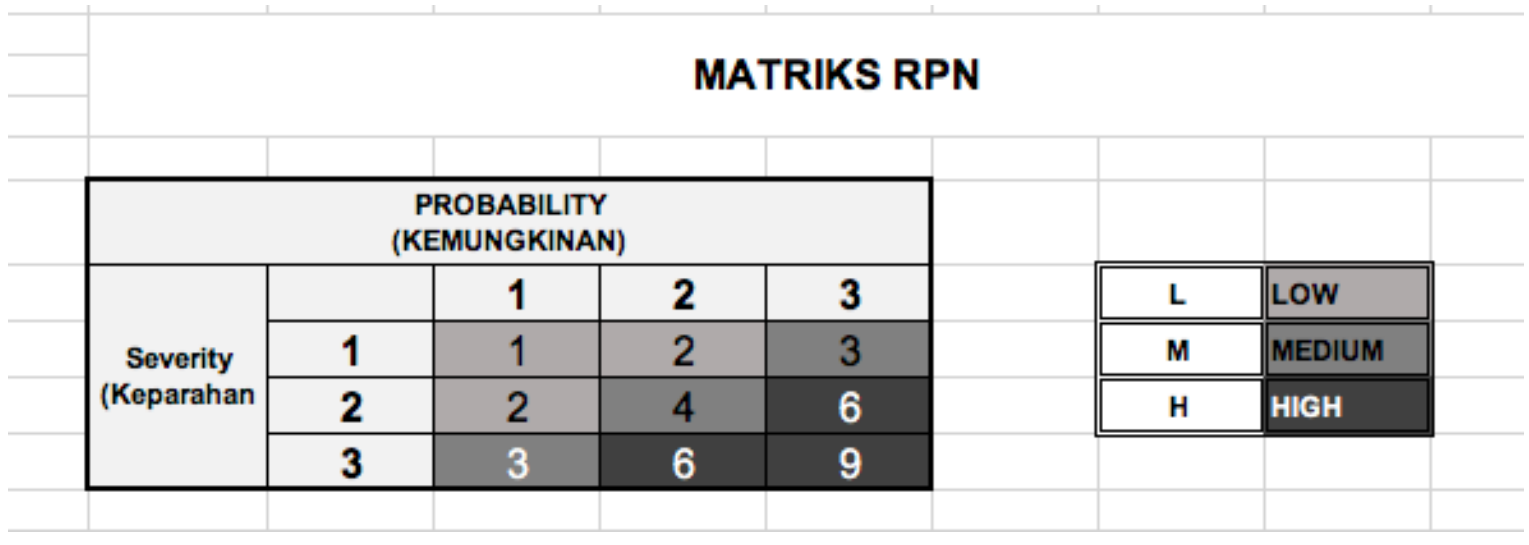

Table 3. Description of Severity, Probability, and Risk Priority

\begin{tabular}{l|l|}
\hline \multicolumn{2}{|c|}{ KETERANGAN FORM IDENTIFIKASI RISK } \\
\hline REGISTER
\end{tabular}


In Kimia Farma's diagnostic related to the above case, it has carried out 5 steps to improve the changes:

1. Organizational restructuring aimed at improving performance and service

2. Strengthening service and supporting systems prioritizing digital and cashless applications

3. Synergy with stakeholders for comprehensive improvement

4. Internal Monitoring System (SPI) which will be deployed to all regions of Indonesia

5. Placement of quality control officers in every branch manager and KFD outlet

There is no complete internal data related to Diagnostic Pharmacy Chemistry that can be presented by the author, but only from the perspective of risk assessment with the PDCA cycle to reduce risk factors that will arise in the future.

a) Plan / Plan: determine and assess risk, to the input process, the process to output.

risk

\section{CONCLUSIONS AND SUGGESTIONS}

The five steps for improving diagnostic pharmaceutical chemistry are considered to be good in solving the problems at hand but perhaps additional and details related to the implementation of improvements must be carried out more consistently and using the PDCA cycle and always include risk-based thinking in all existing processes, namely the $4 \mathrm{M}$ :

1. Man (competency)

2. Method ( SOP, work instructions, etc.)

3. Materials (materials for inspection, reagents, test equipment, etc.)

4. Machine (inspection / test tool)

Suggestions to other researchers to be able to complete the existing or future risks and issues in laboratory companies in general and KF diagnostics in particular.

\section{REFERENCES}

1. Law of the Republic of Indonesia Number 36 the Year 2009 concerning Health.

2. https://national.kontan.co.id/news/requirements-baru-naik-pesawat-dan-kapal-cepat-swabantigen-ini-level-accuracy-cost

3. https://health.detik.com/berita-detikhealth/d-5512201/terbaru-ini-travel-terms-and-expiresswab-pcr-antigen-genose

4. guidelines for the management of rapid antigen tests, PDS PATKLIN, 2020 
E-ISSN: 2808-5361 http://e-journal.fkmumj.ac.id/
Proceeding The First Muhammadiyah InternasionalPublic Health and Medicine Conference

5. https://www.cnnindonesia.com/nasional/20210430075810-12-636731/4-bulan-oknumkimia-farma-practice-antigen-bekas-di-kualanamu.

6. https://www.cnbcindonesia.com/market/20210428123830-17-241486/kimia-farma-angkattalk-dunia-tes-antigen-dengan-alat-bekas)

7. HR. Ibn Majjah. In: Kitab Al Ahkam 2340.

8. National Standardization Body. (2015). ISO 9001:2015. Quality Management Systemsrequirements.

9. Deysher, B. (2015). A Risk-Based Thinking Model for ISO 9001:2015

10. Harrington, HJ, Esseling, EC, \& Nimwegen, HV (1997). Business Process Improvement Workbook. Unites Stated: CWL Publishing Enterprise

11. https://www.bps.go.id/indicator/17/66/1/sum-penumpang-pesawat-di-bandara-utama.html

12. Regulation of the Minister of Health of Republic Indonesia no:411/MENKES/PER/III/2010 Concerning Clinical Laboratory 
Volume I Tahun 2021

November 2021
E-ISSN: 2808-5361

http://e-journal.fkmumj.ac.id/
Proceeding The First Muhammadiyah InternasionalPublic Health and Medicine Conference 